\title{
A system dynamics approach for analyzing supply chain industry: Evidence from rice industry
}

\author{
Maun Jamaludin ${ }^{a^{*}}$, Teddy Hikmat Fauzia ${ }^{\text {, and Deden Novan Setiawan Nugraha }}{ }^{\mathrm{c}}$
}

${ }^{a}$ Department of Business Administration, Faculty of Social and Political Sciences, Pasundan University, Bandung, West Java, Indonesia ${ }^{b}$ Department of Management, Faculty of Economics and Business, Widyatama University, Bandung, West Java, Indonesia

\section{H R O N I C L E}

Article history:

Received April 15, 2020

Received in revised format June

8,2020

Accepted July 272020

Available online

July 272020

Keywords:

Supply chain

Rice Industry

System Dynamics

Policy Strategy

\section{A B S T R A C T}

The rice industry policy must be comprehensive with a scope of policy from upstream to downstream. In other words, it must cover all supply chains of the rice industry consisting of five levels, such as, the level of farmers who process rice, grain traders, rice traders, rice traders in production areas and rice traders in urban markets. The purposes of this research are (1) to identify and model the current supply chain system of the rice industry; (2) analyze the simulation of the rice industry supply chain system policy; and (3) recommend rice industry policies which provide incentives for all rice industry supply chain actors. The research method used is the case study method. The aim is to understand a phenomenon in the rice industry supply chain system in depth in West Java Province - Indonesia. The results show that the rice industry supply chain system model is a closed cycle consisting of material flow feedback in the form of grain, rice, money and information flow in the form of demand that occurs in the interaction of actors from farmers, grain traders, rice milling units (RMU), rice traders in production centers to rice traders in urban wholesale markets in Bandung and Jakarta. Every businessman in the rice industry has the same goal, which is to maximize the profits. Thus, it can potentially lead to a conflict of interest which is manifested in the desire of every businessman to sell as much as they produce at the highest possible price but this will not happen because of the limited resources they have, such as capital and the market demand they receive. The strategy of increasing production is often carried out by the government at this time which it cannot be done partially without considering other rice industry supply chain instruments. The impacts of this partial policies are farmers, collectors, rice traders and rice mills gain unstable profits and the benefits received are lower than before the production strategy and policy were implemented. The recommended policy strategy is the rice industry supply chain system should be able to guarantee the availability of sufficient rice and capable of guaranting the welfare of farmers with a policy that integrates rice farming and agro-industry production strategies, financing strategies and accessible to all levels of actors in the rice industry supply chain, human resource development strategies and rice business risk management strategies, simultaneously. The integrated policy strategy needs to be carried out since rice supply chain management is a coordinating system of material flow in the form of grain, rice, money, facilities and information flow in the form of orders or requests, knowledge and innovation.

(C) 2021 by the authors; license Growing Science, Canada.

\section{Introduction}

Rice is the most strategic food commodity in create national food security. The changes are occurring on the production side and the consumer side cause a variety of classic problems arise in the rice industry in Indonesia (Novar et al., 2018; Purwandoko \& Seminar, 2019). Every year there is an excess of production as a result of the harvest that occurs in production centers, causing farmers as producers to receive reduced income due to falling grain

* Corresponding author

E-mail address: maunjamaludin.unpas@yahoo.com (M. Jamaludin)

(C) 2021 by the authors; licensee Growing Science.

doi: 10.5267/j.uscm.2020.7.007 
prices. The problems faced by other businessman in the rice industry, such as grain brokers, milling industry and rice traders. In other words, the rice industry experiences the problem of scarcity of rice supply which results in consumers having to pay more. The scarcity of rice supply was due to a shortage of grain supply and rice from grain production centers. This phenomenon is repeated every year and seems to have never been resolved by various government policies. Government policies in the rice industry only focus on aspects of increasing the efficiency and productivity of rice production/aquaculture systems (McCulloch \& Peter Timmer, 2008). The efficiency of the rice production system is only carried out with intensification quality improvement programs, integrated rice and livestock farming systems, production of seeds or new varieties and other similar programs (Panuju et al., 2013; Afiff \& Timmer, 1971). Thus, rice industry programs are not only aimed at increasing rice productivity and cropping index in the hope of increasing rice availability but also consumers can consume rice at lower prices. The formulation and implementation of the rice industry policy must be comprehensive and systemic with the policy scope from upstream to downstream. In addition, it must cover the entire rice industry supply chain network with a minimum of five levels, such as the level of farmers who cultivate rice in fields, the level of grain intermediary traders such as croupier or wholesaler, the level of rice milling, the level of rice traders at centers rice production and traders in the urban wholesale market. Based on the background of the above research, the problem to be formulated to be studied is to analyze the current supply chain model of the rice industry.

\section{Research Methods}

The research method used in this research is a case study method that aims to understand a phenomenon in the rice industry supply chain system in depth in West Java Province. This study used a 'System Dynamics' approach which used perspectives based on information feedback and 'delays' to understand the dynamics of complex system behavior from physical systems, biological systems and social systems (Bell et al., 2003). It was largely used to analyze the supply chain management, logistics and distribution (Sachan et al., 2005; Spengler \& Schröter, 2003; Campuzano \& Mula, 2011; Lertpattarapong, 2002; Asgari, \& Hoque, 2013). The main assumption in the 'System Dynamics' approach is the structure of the phenomenon of the decision-making process which is a collection (assembly) of causal structures who are circular and closed (Sterman, 2000; Lee et al., 2012; Wankhade \& Dabade, 2006). The purposes of this research are (1) to identify and model the current rice industry supply chain system; (2) analyzing policy simulation of the development of the rice industry supply chain system; and (3) recommending the rice industry policy which provides incentives for all businessman rice industry supply chain.

\section{Literature Reviews}

The term supply chain is commonly defined as efforts to deliver goods or services from suppliers to consumers by involving activities, resources and technology, from organizations and people (Kozlenkova et al., 2015; Nagurney, 2006). In the business world, supply chains are defined as a series of value-adding activities found between raw material supply side companies and demand for end products. In supply chain activities, information plays a very important role (Lau \& Lee, 2000; Narasimhan \& Kim, 2001). In the case of rice, supply chain management includes purchasing raw materials (grain) from farmers, transportation to rice mills, processing (drying and grinding) in factories, packaging, warehousing, and distribution to various traders (wholesalers and retailers) and finally to consumers. According to Mentzer et al. (2001), the supply chain is a group of three or more entities (organizations and individuals) which are directly involved in the upstream and downstream flow of products, services, finance and or information from a source to consumer. The supply chain is a complex network of facilities and several organizations that have different goals and interests. The involvement of many businessmen who have different goals makes the problem in supply chain management complex (Woods, 2004; Croxton et al., 2001; New, 1997). This raises various management problems, such as: (1) fluctuating demand is a major challenge in determining production capacity; (2) systems that vary over time, production planning must consider demand and costs that can change due to seasonal factors, as well as promotional and pricing strategies carried out by competitors; and (3) some problems in the supply chain are new, such as product life cycles that are getting shorter in an industry (Roekel et al., 2002).

The model is an abstract depictional system that acts like a real system for certain aspects (Manetsch and Park, 1977). According to Eriyatno (1999) the model is an abstraction from reality, which will show a direct or indirect relationship or a causal relationship. A model can be said to be complete if it can represent various aspects of the reality being studied. Forrester (1980) states the model developed with system dynamics has the following characteristics: (a). describe the causal relationship of the system; (b). simple in mathematical nature; (c). synonym with industrial, economic and social terminology in nomenclature, and; (d). can involve changes that are not continuous if the decision is needed. The System Dynamics approach is a modeling method with computer simulations, which was developed at MIT in the 1950s as a tool used by managers to analyze complex problems. System Dynamics is able to create a learning environment, a laboratory that acts like a miniature of the system. System Dynamic is a methodology of thinking, a methodology for abstracting a phenomenon in the real world into a more explicit model (Sterman J.D. 2000). 


\section{Results and Discussions}

\subsection{General Models of Rice Industry Supply Chain}

Rice industry supply chain in West Java is a closed cycle consisting of material flow feedback in the form of grain, rice, money and information flow in the form of demand that occurs in the interaction of the rice industry from farmers to rice traders in the main markets in Bandung (Caringin and Gede Bage main markets) and Jakarta (Cipinang Central Market). Each material and information flow that occurs is the result of a decision made by each rice industry businessman (Figure 1). The farmers will send the grain produced by their farmers to the traders, then their grain will be reduced. Likewise, the same phenomenon also occurs in other rice industry, such as rice mills selling rice to rice traders who are in the wholesale market located in Bandung and Jakarta. Thus, the sales decision will directly reduce the supply of rice owned by rice mills. Every decision phenomenon that occurs at every level of the rice industry always have a negative feedback loop which will produce behaviors that lead to balanced and lead to the achievement of goals.

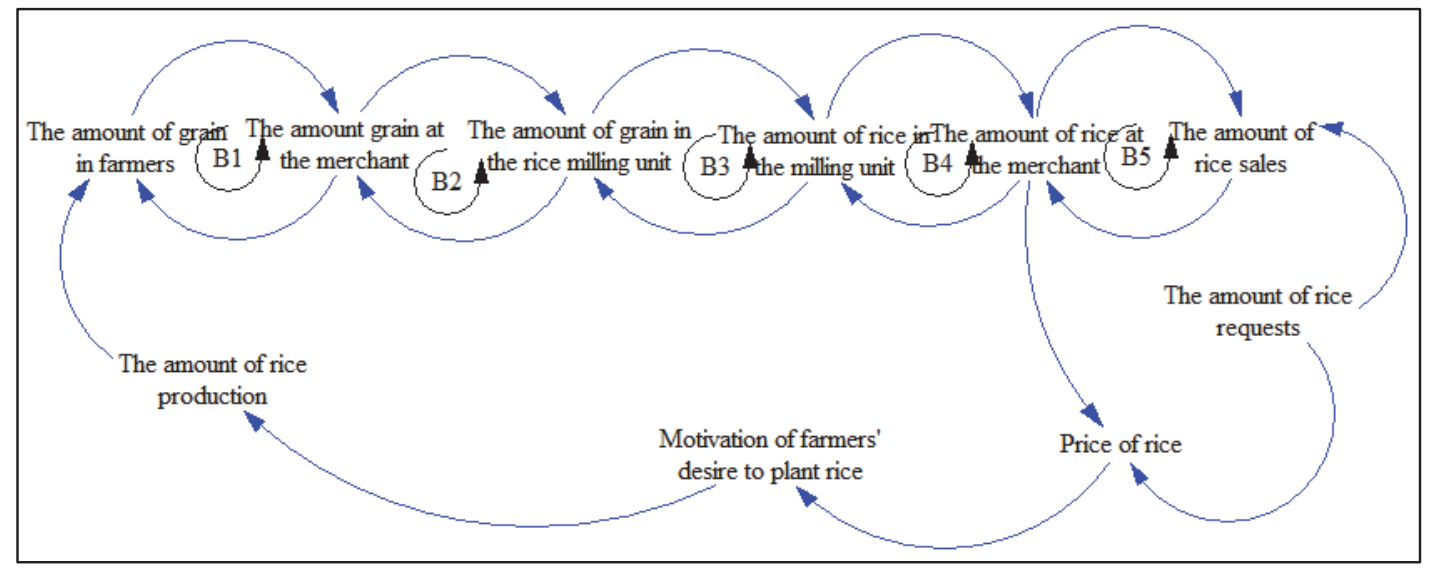

Fig. 1. The Feedback Diagram of the Basic Structure of the Rice Supply Chain

The rice industries businessman has the same goal such as to maximize the profits they want to achieve, thus creating a conflict of goals which is manifested in the desire of every actor who wants to sell as many products as possible at the highest possible price. It did not happen because of the limited resources available, such as capital and market demand received. It can be compromised in the form of material and information adjustments when interactions occur between them. It arises the dynamics of material flow, and information in the rice supply chain or better known as the oscillation or bullwhip effect (Sterman, 2000). In addition, there is still negative feedback arising from a causal relationship between farmers as decision makers in rice production and markets which are reflected in rice prices. With the increase in the price of rice, it can encourage an increase in the desire of farmers to grow rice. The desire is carried out by planting rice which will increase rice production. Increased rice production has resulted in increased grain availability then the volume of grain sales at collectors and mills is increasing. An increase in grain purchases in mills causes the amount of rice production to increase then the volume of rice traded at the level of rice traders' increases. The increasing volume of rice trade will reduce or reduce the price of rice in the market. The price of rice is down, making the enthusiasm of farmers to grow rice to decline and it continues on the decline in the volume of grain and rice trade. Without a new decision structure, the phenomenon will always be repeated and will lead to a balance.

\subsection{The Basic Structure of the Rice Industry Supply Chain System}

This section will discuss the two basic structures forming rice supply chain management in West Java. The two basic structures are the basic structure of rice flow and the basic structure of money flow. In the rice flow structure, there is directly a basic structure of information flow in the form of orders or demands at each level of businessman (Figures 2,3 and 4). Fig. 2 shows the basic structure of rice flow from the level of farmers, croupier, RMU (rice milling unit) and rice traders. Starting from rice production at the farm level followed by a process of drying the farmers' rice which results in the accumulation of stored dry grain (SDT) which is ready for sale by farmers. The farmers of SDT inventory are reduced due to sales to collectors and / or dealers. Farmers sell their unhusked rice based on the highest selling price of dry unhusked rice to be received and there is a good relationship with market participants. The traders and dealers will make a number of purchases of grain in accordance with the purchasing power they have. The purchasing power is determined by the availability of cash owned by each business actor. The traders do not conduct transactions directly with the unit of the owner of the rice mill, but they do transactions with the bookie or the middlemen. Then the SDT accumulates in the city will sell the rice to the owner of the rice milling unit to be processed into rice or sold again to the rice traders. The rice traders will utilize the services of the rice milling unit to process Grinded Dry Grain (GDG) owned by them into ready-to-sell rice. 


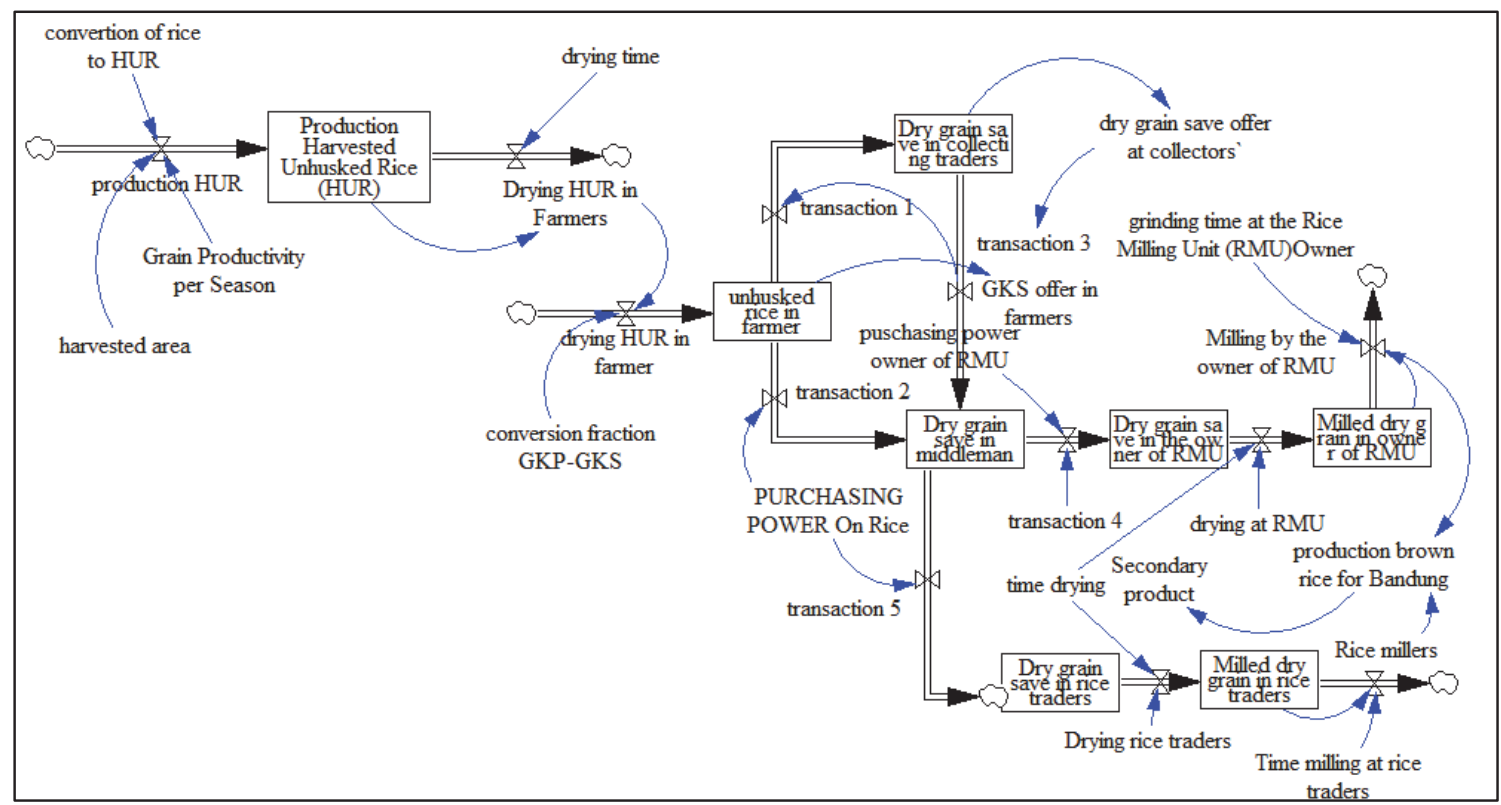

Fig. 2. The Basic Structure of Rice Flow

In Fig. 3, it is clear that rice production in West Java is the accumulation of the results of the milling process carried out by the owner of the Rice Milling Unit and rice traders. Then the rice will be sold to rice traders in the cities of Bandung and Jakarta. Every transaction made from the farmer level to the rice traders in the urban wholesale market will form a negative feedback loop. To produce a process that leads to be a balancing process of the availability of grain or rice. The process will always repeat itself because there is no new decision structure in the form of product, process or institutional innovation (Mufti et al., 2019). This condition causes the phenomenon of scarcity and excess rice to always recur, as if not resolved like a virtuous and vicious cycle. The phenomenon of scarcity or oversupply of rice is always intervened by the central and regional governments by changing the decision parameters in the form of adding or reducing the flow of rice in the community by carrying out market operations by the Logistics Agency. The changes in behavior by the government are only temporary because there is no new decision structure that is able to overcome the phenomenon permanently or continuously

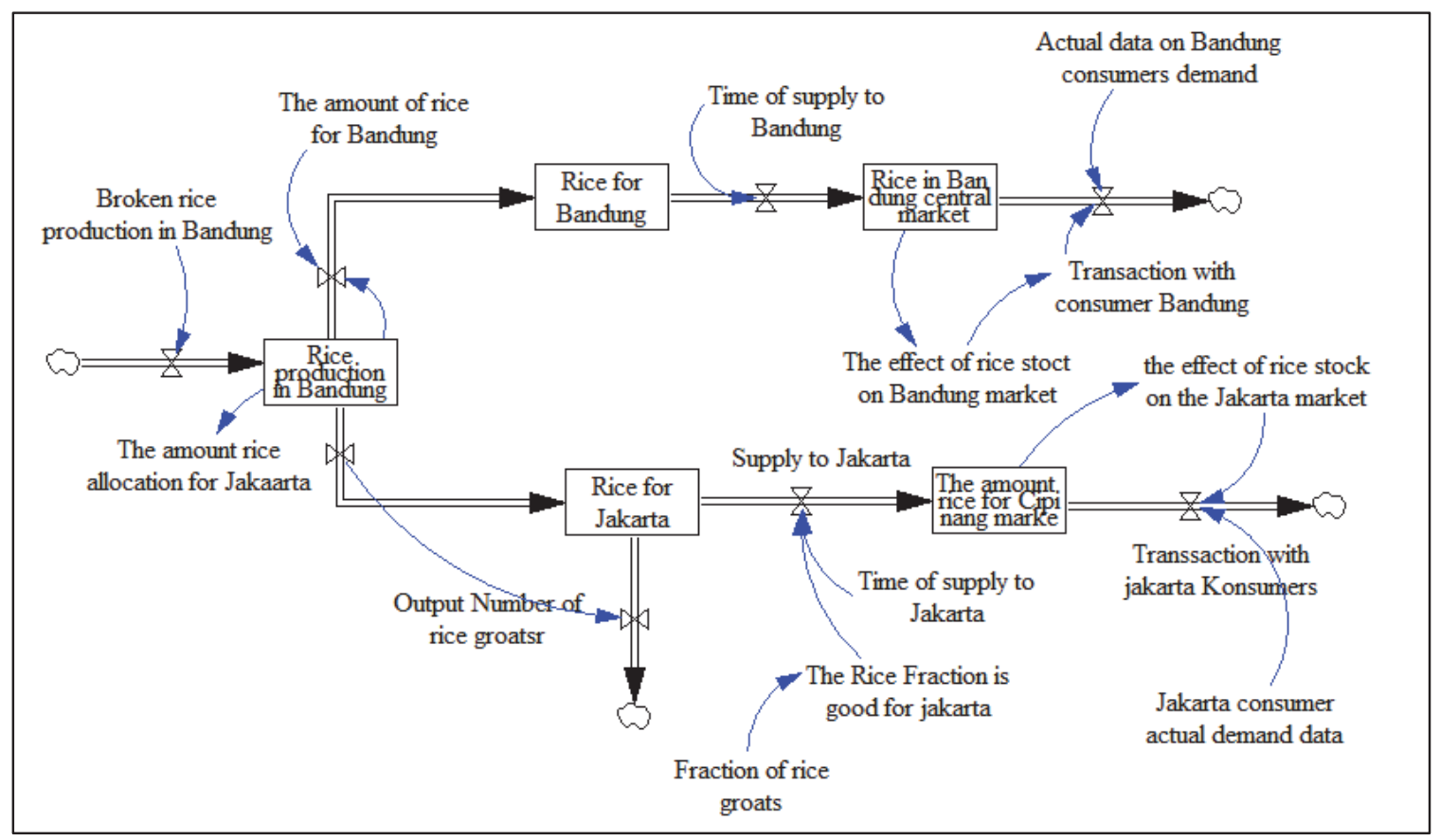

Fig. 3. The Basic Structure of Rice Flow (Continued) 
There is often overlooked in the decision of rice supply chain management is the structure of the flow of money that occurs in the perpetrators of rice in West Java. The flow of money is the result of feedback from the flow of rice that occurred at that time. Money is a limited resource; it will determine the amount of rice flow that occurs (Fig. 4). The basic structure of the money flow that occurs in the rice supply chain system in West Java is the interaction of the money supply at each level of the actors involved. The decision on the purchase of grain or rice and the income received from the transaction process that occurs between one actor and another. The availability of cash held by each actor and market demand will determine the purchasing power for the procurement of grain or rice. The increased cash amount will increase purchasing power which will increase the amount of grain or rice purchases. Conversely, the increasing number of purchases of grain or rice will reduce the amount of cash available. The behavior of the decision and physical structure will lead to balance and if there is no new structure will result in a repetitive phenomenon. The smooth flow of cash in the rice supply chain system is determined by the availability of cash that will be depressed or disrupted if there are changes in decision parameters such as increasing the amount of grain or rice circulation due to the harvest season. Great harvest will result in market participants dealing with two alternative decisions, such as buy at the same price in greater quantities but delay payment or buy more by paying in cash but at a lower price. Usually, market participants will choose the second decision, which is to buy more in cash at a lower or lower price. The situation will be transmitted from upstream to downstream or from grain to rice. The phenomenon always occurs repeatedly in the rice supply chain system in West Java especially and in Indonesia in general.

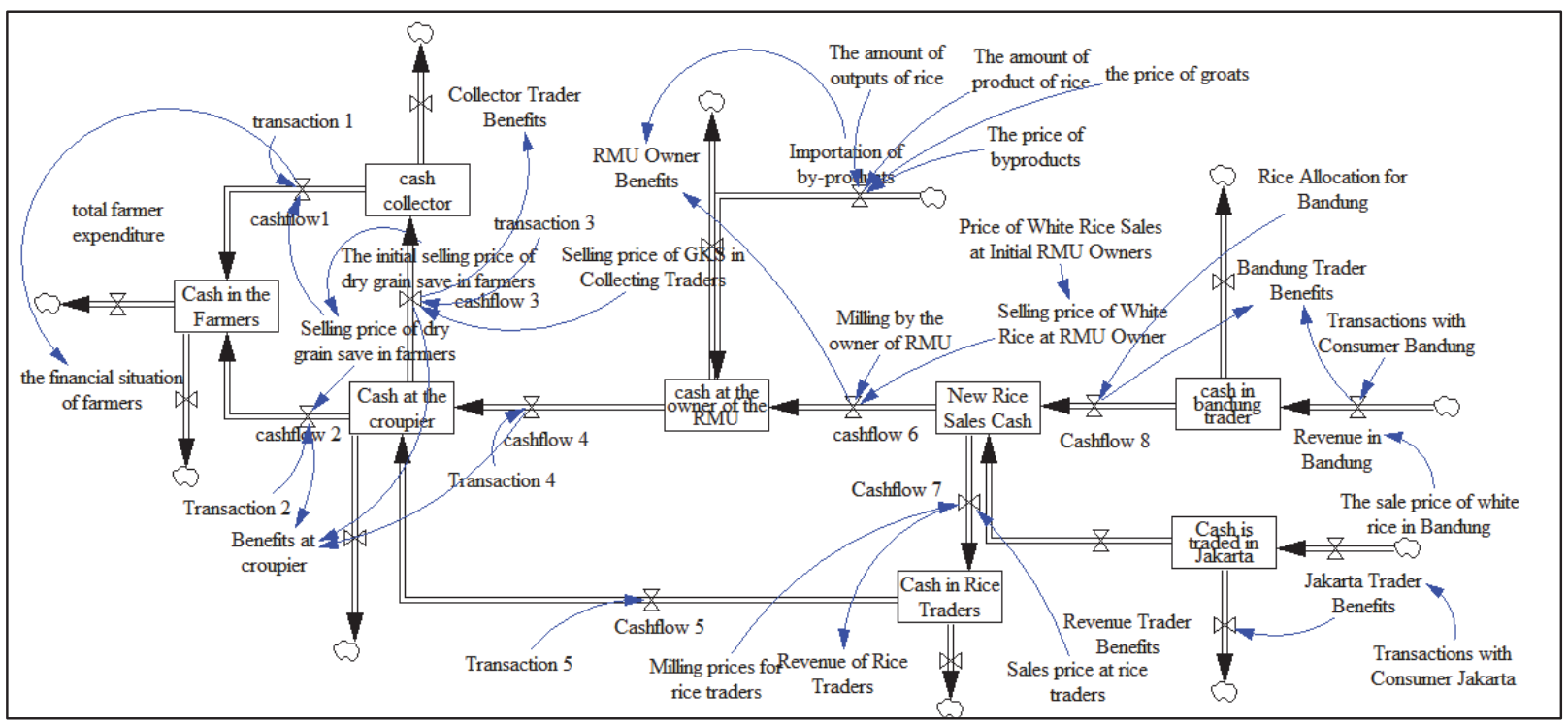

Fig. 4. Basic Structure of Money Flow

\subsection{The Strategy Simulation of Rice Industry Supply Chain System Model}

This section is a development of the basic structure of rice flow and money flow in the rice industry supply chain system in West Java. These two basic structures (rice and money flow) above are converted into stock and flow diagrams which are then converted into a simulation model using Vensim PLE 8.0.9 software. This simulation model is based on the level of actors involved, such as: farmers, collectors, traders, rice traders, rice mill owners, aggregates of West Java, rice traders in Jakarta and rice traders in Bandung. In the simulation model at each level the actors are integrated from the physical flow in the form of rice flow and cash flow as well as information flow in the form of requests. Based on the integration model, a simulation is carried out by changing parameters that reflect the policy of increasing rice production which is often applied by the Agriculture and Food Crops Office of West Java Province as the technical authority of rice and rice production in West Java Province. The production strategy undertaken by the central government and the agricultural service and food crops of West Java province in the rice supply chain supply system in West Java Province is by increasing productivity and changing the number of planting seasons (cropping index). Increased productivity is done by changing cultivation technology both changes in technological components and technology models. The technological component applied is the change in the use of varieties, the use of organic fertilizers, pest and disease control, how to plant and other technology components that are applied separately (Pudjiarti \& Darmanto, 2020). Furthermore, the technology model is a combination of several technological components that are applied to farmers simultaneously, such as an integrated farming system, rice and livestock integration. Based on the application of the production strategy, a simulation of the decision structure and physical structure of the actual conditions of the rice supply chain system in the province of West Java is carried out. The simulation will be carried out by changing rice productivity and changing the number of planting seasons. 

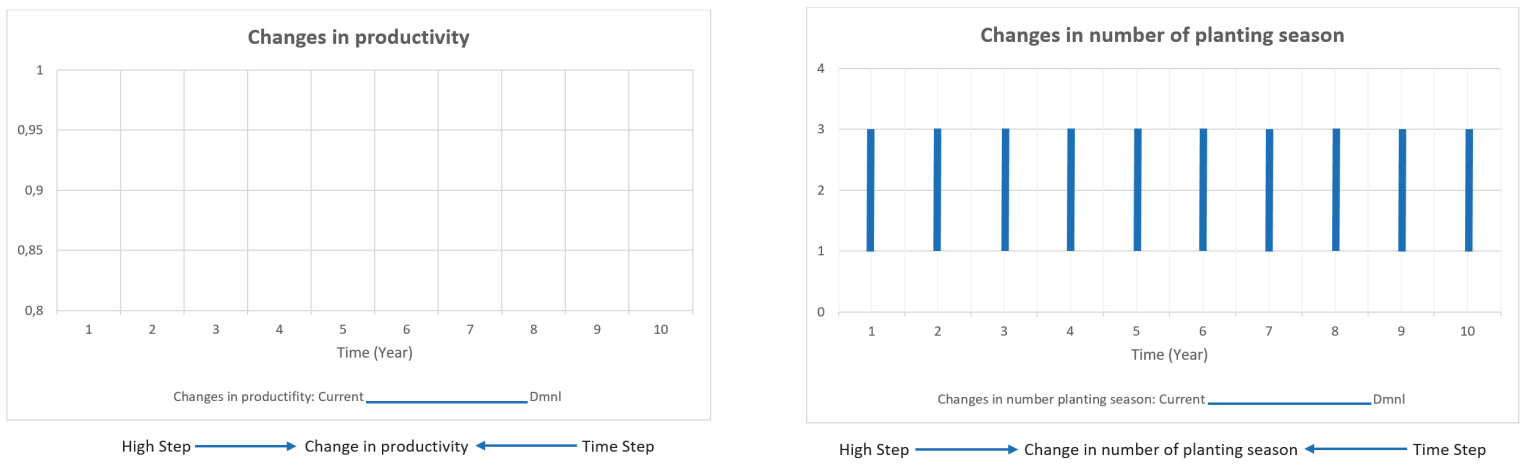

Fig. 5. Simulated Model Parameters

The model is simulated with a configuration like Fig. 5, that in year 2, the average number of planting seasons from 2 was increased to 2.5 times the planting season. Increasing both parameters will result in higher grain and rice productivity than the actual condition. Based on the results of the simulation, the results obtained that the stock of grain in farmers, collectors and dealers increased.
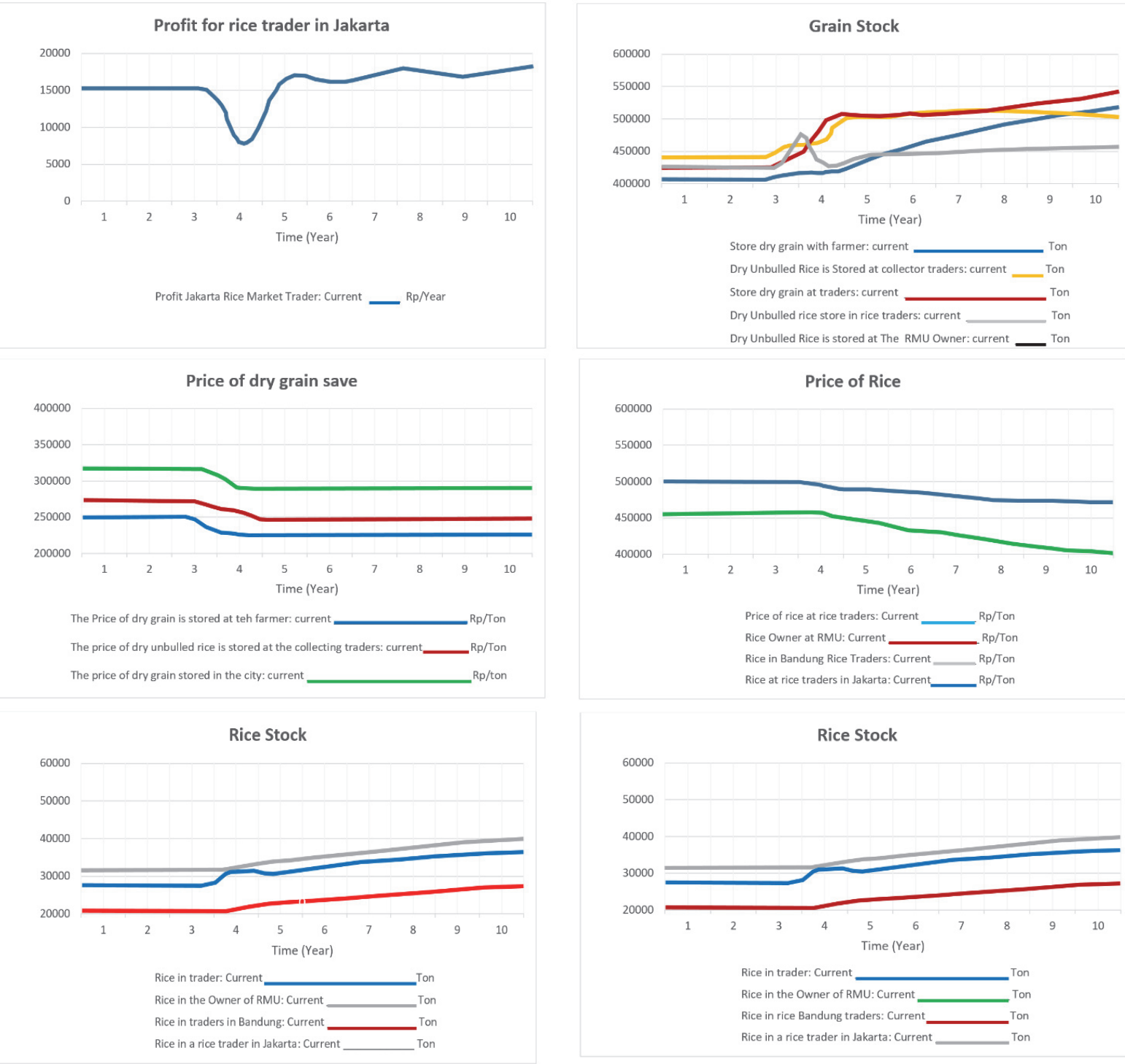

Fig. 6. The Dynamics of Grain and Rice Inventory and Prices 
Likewise, the increase occurred in rice stock in the owners of the rice mill/RMU unit, rice traders in West Java Province, rice traders in Jakarta and Bandung (Fig. 6). The increased supply of unhusked rice and rice is caused by the lower grain price and the price of rice. The rice industry players rationally refrain from selling grain and rice at low price conditions and storing grain and rice as supplies. They will sell grain and rice at the right time, i.e. when the price of grain and rice has risen. Thus, an increase in productivity and the number of growing seasons, causes not all rice industry players involved to benefit from their business. Farmers as rice industry players in the upstream sector experience losses at the beginning of an increase in production, then experience an increase in certain circumstances, resulting in a significant decline. Then, subsequently slowly increasing again but still below the benefits received before the production strategy and policy is implemented. The tendency of profits received by collectors, traders, rice traders and owners of rice milling units in rice production centers have the same behavioral tendencies, namely the profits received are unstable and the benefits received are lower when compared to before strategy and policy production applied. This situation is different from that experienced by rice traders in the Cipinang Jakarta main market and traders in the rice market in Bandung such as the Caringin wholesale market and the Gede Bage Main Market, which experienced gains with a tendency to increase after a short period of decline (Fig. 7). Based on these dynamics, grain and rice stocks, grain and rice prices and profits for each rice business actor involved in the rice industry supply chain can be concluded that the strategy of increasing production that is often carried out by the central government and regional governments cannot be carried out partially without regard to the instrument development of other rice industry supply chains. This happens because an increase in rice production requires an increase in purchasing power or the availability of cash in such a way that the supply of grain and rice can be purchased, and the supply chain runs normally.
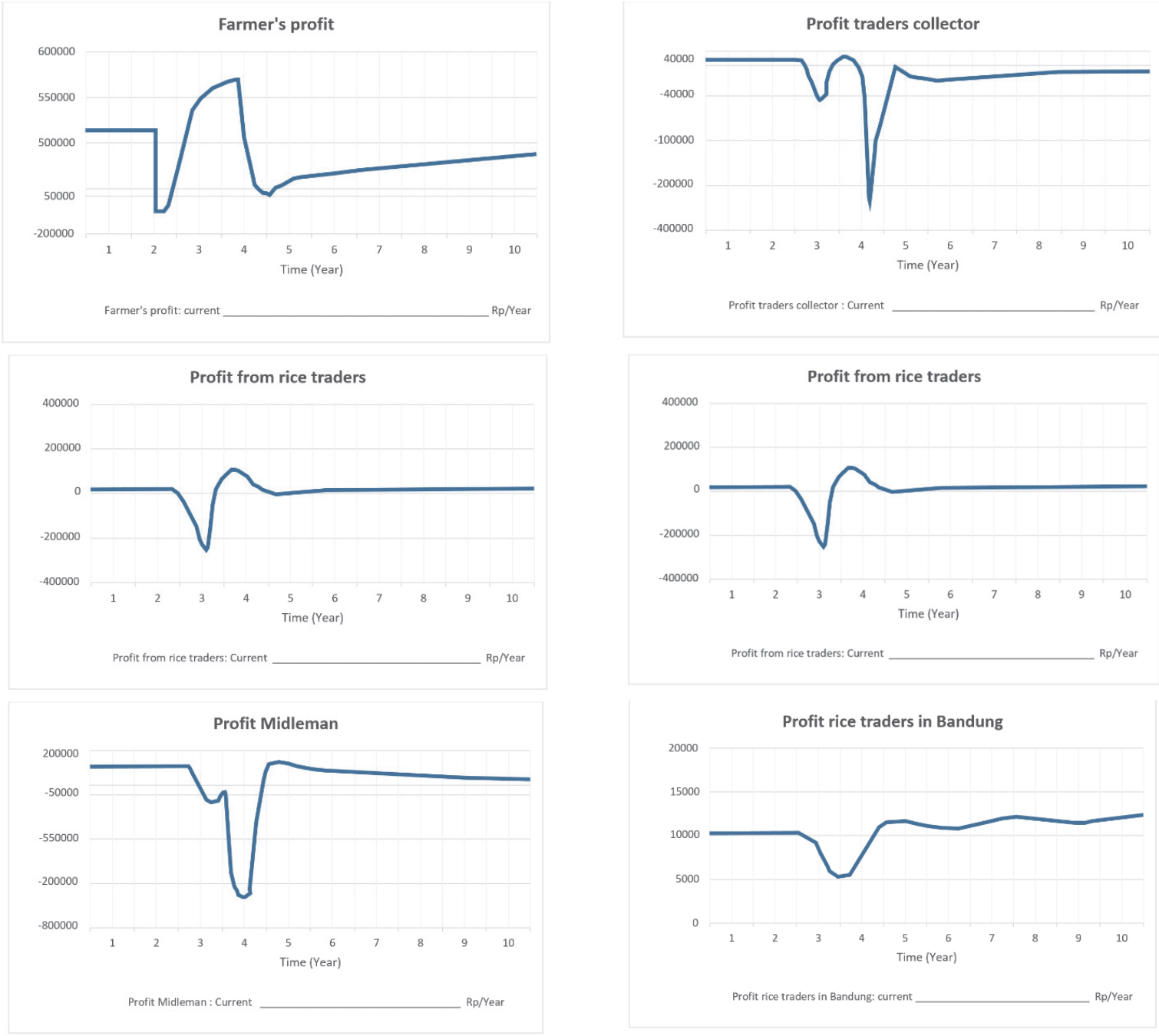

Fig. 7. The Dynamics of Profit at each Level of Actors

Rice industry supply chain policy strategies that can guarantee sufficient rice availability and are able to guarantee welfare for farmers should integrate rice production and agro-industry production strategies, financing strategies that are accessible to all levels of rice business actors involved in the rice industry supply chain, resource development strategies people and 
strategies for managing the rice industry supply chain business risks simultaneously and continuously (Wong et al., 2010; Nguyen et al., 2019; Sathapatyanon et al., 2018; Wu, 2013)). The integrated strategy is necessary and immediate because the management of the rice supply chain is a coordinating system of material flow in the form of grain, rice, money, facilities and information flow in the form of orders or requests, ideas and knowledge as well as innovation (Berghman et al., 2012; Jimenez-Jimenez et al., 2019; Yoon et al., 2016; Kim et al., 2006; Chang et al., 2019). The main aspect that needs to be considered is a learning system at all levels of the rice industry that is involved and able to create new innovations to produce sustainable competitiveness and prosperity (Wang \& Hu, 2020; Spekman et al., 2002; Li et al., 2018; Pudjiarti \& Hutomo, 2020). By paying attention to the learning system, it is also hoped that a fair rice industry supply chain system can be created which is characterized by the absence of exploitation among the business actors involved.

\section{Conclusions}

The rice industry supply chain system model is a closed cycle consisting of material flow feedback in the form of grain, rice, money and information flow in the form of demand that occurs in the interaction of actors from farmers, grain traders, rice milling units (RMU), rice traders in production centers to rice traders in urban wholesale markets in Bandung and Jakarta. Every material and information flow that occurs is the result of decisions made by each rice industry supply chain businessman. The results highlight that every businessman in the rice industry has the same goal, which is to maximize the profits it receives. It can potentially lead to conflicts of interest that manifest in the desire of each businessman to sell as many products as they produce at the highest possible price. It will not happen because of the limited resources they have, such as capital and the market demand they receive. It leads to decisions that can be compromised such as material and information adjustments when the interaction occurs between them. Thus, it can potentially lead to a conflict of interest which is manifested in the desire of every businessman to sell as many products as they produce at the highest possible price but this will not happen because of the limited resources they have, such as capital and the market demand they receive. The strategy of increasing production is often carried out by the government at this time which it cannot be done partially without regard to other rice industry supply chain instruments. The impact of this partial policies are farmers, collectors, rice traders and rice mills gain unstable profits and the benefits received are lower than before the production strategy and policy were implemented. The current strategy of increasing production which is often carried out by the government cannot be carried out partially without regard to other rice industry supply chain instruments. The impact of this partial policy is farmers, traders, rice traders and rice mills. The result is unstable profits and lower profits compared to before the production strategy and policy were implemented. This condition is different from that experienced by rice traders in the wholesale market in Bandung such as the Caringin main market, Gede Bage and traders in the rice market in Jakarta such as the Cipinang main market, which experience profits with a tendency to increase. This happens because an increase in rice production requires an increase in purchasing power or the availability of cash in such a way that the supply of grain and rice can be purchased, thus the supply chain runs normally. The recommended policy strategy is the rice industry supply chain system which is able to guarantee the availability of sufficient rice and able to guarantee the welfare of farmers. One of them is a policy that combines rice farming and agro-industry production strategies, financing strategies which are accessible to all levels of actors in the rice industry supply chain, human resource development strategies and strategies for managing rice supply chain business risks simultaneously. This integrated policy strategy needs to be carried out because rice supply chain management is a coordinating system of material flow in the form of grain, rice, money, facilities and information flow in the form of demand, knowledge and innovation.

\section{References}

Afiff, S., \& Timmer, C. P. (1971). Rice policy in Indonesia. Food Research Institute Studies, 10(1387-2016-116168), 131159.

Asgari, B., \& Hoque, M. A. (2013). A system dynamics approach to supply chain performance analysis of the ready-madegarment industry in Bangladesh. Ritsumeikan Journal of Asia Pacific Studies, 32(1), 51-61.

Bell, C., Higgs, R., Vickers, S., Toncinich, S., \& Haslett, T. (2003). Using Systems Modelling to Understand The Dynamics of Supply Chains. Department of Management (Australia: Faculty of Business and Economics. Monash University).

Berghman, L., Matthyssens, P., \& Vandenbempt, K. (2012). Value innovation, deliberate learning mechanisms and information from supply chain partners. Industrial Marketing Management, 41(1), 27-39.

Campuzano, F., \& Mula, J. (2011). Supply chain simulation: A system dynamics approach for improving performance. Springer Science \& Business Media.

Chang, H. H., Wong, K. H., \& Chiu, W. S. (2019). The effects of business systems leveraging on supply chain performance: Process innovation and uncertainty as moderators. Information \& Management, 56(6), 103140.

Croxton, K. L., Garcia-Dastugue, S. J., Lambert, D. M., \& Rogers, D. S. (2001). The supply chain management processes. The International Journal of Logistics Management, 12(2), 13-36.

Eriyatno. (1999). Systems Science: Improving the Quality and Effectiveness of Management. Bogor: IPB Press

Forrester, J. W. (1980). Information sources for modeling the national economy. Journal of the American Statistical Association, 75(371), 555-566.

Jimenez-Jimenez, D., Martínez-Costa, M., \& Rodriguez, C. S. (2019). The mediating role of supply chain collaboration on the relationship between information technology and innovation. Journal of Knowledge Management, 23(3). 
Kim, D., Cavusgil, S. T., \& Calantone, R. J. (2006). Information system innovations and supply chain management: channel relationships and firm performance. Journal of the academy of marketing science, 34(1), 40-54.

Kozlenkova, I. V., Hult, G. T. M., Lund, D. J., Mena, J. A., \& Kekec, P. (2015). The role of marketing channels in supply chain management. Journal of Retailing, 91(4), 586-609.

Lau, H. C., \& Lee, W. B. (2000). On a responsive supply chain information system. International journal of physical distribution \& logistics management, 30 (7/8), 598-610

Lee, S., Geum, Y., Lee, H., \& Park, Y. (2012). Dynamic and multidimensional measurement of product-service system (PSS) sustainability: a triple bottom line (TBL)-based system dynamics approach. Journal of cleaner production, 32, 173-182.

Lertpattarapong, C. (2002). Applying system dynamics approach to the supply chain management problem (Doctoral dissertation, Massachusetts Institute of Technology).

Li, M., Jian, Z., Li, L., \& Yeung, T. K. H. (2018). Effects of organisational learning on service innovation performance: the mediating effect of supply chain collaboration and the moderating role of interpersonal trust. International Journal of Services Technology and Management, 24(1-3), 43-61.

Manetsch, T.J. \& Park, G.L. (1977). System Analysis Defining Supply Chain Management. Journal and Si mulation with Applications to Economic and Social Systems, 3rd edition. Department of Electrical Engineering and System Science, Michigan State University, East Lansing, Michigan

McCulloch, N., \& Peter Timmer, C. (2008). Rice policy in Indonesia: a special issue. Bulletin of Indonesian Economic Studies, 44(1), 33-44.

Mentzer, J. T., DeWitt, W., Keebler, J. S., Min, S., Nix, N. W., Smith, C. D., \& Zacharia, Z. G. (2001). Defining supply chain management. Journal of Business logistics, 22(2), 1-25.

Mufti, M.Y., Pudjiarti, E.S., \& Darmanto, S. (2019). Analysis of Second Order Person-Environment Fit on Innovative Work Behavior and Individual Performance. Arthatama, 5(2), 1-12.

Nagurney, A. (2006). Supply chain network economics: dynamics of prices, flows and profits. Edward Elgar Publishing.

Narasimhan, R., \& Kim, S. W. (2001). Information system utilization strategy for supply chain integration. Journal of business logistics, 22(2), 51-75.

New, S. J. (1997). The scope of supply chain management research. Supply Chain Management: An International Journal, 2(1).

Nguyen, H. K., Chiong, R., Chica Serrano, M., Middleton, R. H., \& Pham, D. T. K. (2019). Contract Farming in the Mekong Delta's Rice Supply Chain: Insights from an Agent-Based Modeling Study. Journal of Artificial Societies and Social Simulation, 22(3), 1-1.

Novar, M. F., Ridwan, A. Y., \& Santosa, B. (2018, October). SCOR and ahp based monitoring dashboard to measure rice sourcing performance at Indonesian bureau of logistics. In 2018 12th International Conference on Telecommunication Systems, Services, and Applications (TSSA) (pp. 1-6). IEEE.

Panuju, D. R., Mizuno, K., \& Trisasongko, B. H. (2013). The dynamics of rice production in Indonesia 1961-2009. Journal of the Saudi Society of Agricultural Sciences, 12(1), 27-37.

Pudjiarti, E. S., \& Hutomo, P. T. P. (2020). The critical role of effective organizational learning to improve firm's innovation and performance in a market turbulence condition. International Journal of Innovation Science.

Pudjiarti, E., \& Darmanto, S. (2020). Interactive control capability, effective organizational learning and firm perfor-mance: An empirical study of milling and metal industry in Tegal. Management Science Letters, 10(3), 575-584.

Purwandoko, P. B., \& Seminar, K. B. (2019). Development of a smart traceability system for the rice agroindustry supply chain in indonesia. Information, 10(10), 288.

Roekel J. V., Willems S., \& Boselie, D. M. (2002). Agro-Supply Chain Management - To Stimulate Cross-Border Trade in Developing Countries and Emerging Economies. World Bank.

Sachan, A., Sahay, B. S., \& Sharma, D. (2005). Developing Indian grain supply chain cost model: a system dynamics approach. International Journal of Productivity and Performance Management.

Sathapatyanon, J., Kuwornu, J. K., Shivakoti, G. P., Soni, P., Anal, A. K., \& Datta, A. (2018). The role of farmer organizations and networks in the rice supply chain in Thailand. Journal of Agribusiness in Developing and Emerging Economies, 8(3).

Spekman, R. E., Spear, J., \& Kamauff, J. (2002). Supply chain competency: learning as a key component. Supply chain management: An international journal, 7(1), 41-55.

Spengler, T., \& Schröter, M. (2003). Strategic management of spare parts in closed-loop supply chains-a system dynamics approach. Interfaces, 33(6), 7-17.

Sterman, J. D. (2000). Business Dynamics: Systems Thinking and Modeling for a Complex World. Business Dynamics: Systems Thinking and Modeling for a Complex World. McGraw Hill.

Wang, C., \& Hu, Q. (2020). Knowledge sharing in supply chain networks: Effects of collaborative innovation activities and capability on innovation performance. Technovation, 94, 102010.

Wankhade, L., \& Dabade, B. M. (2006). TQM with quality perception: a system dynamics approach. The TQM magazine.

Wong, L. C., Emrus, S. A., Bashir, B. M., \& Tey, J. Y. (2010, June). Malaysian Padi \& Rice Industry: Applications of Supply Chain Management Approach. In National Rice Conference Swiss Garden Golf Resort Lumut (pp. 28-30).

Woods, E. J. (2004). Supply-chain management: Understanding the concept and its implications in developing countries. In ACIAR proceedings (pp. 18-26). ACIAR; 1998.

$\mathrm{Wu}, \mathrm{G}$. C. (2013). The influence of green supply chain integration and environmental uncertainty on green innovation in 
Taiwan's IT industry. Supply Chain Management: An International Journal.

Yoon, S. N., Lee, D., \& Schniederjans, M. (2016). Effects of innovation leadership and supply chain innovation on supply chain efficiency: Focusing on hospital size. Technological Forecasting and Social Change, 113, 412-421.

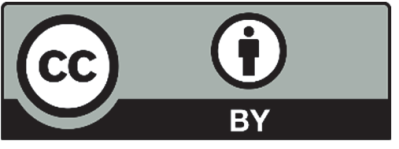

(C) 2021 by the authors; licensee Growing Science, Canada. This is an open access article distributed under the terms and conditions of the Creative Commons Attribution (CC-BY) license (http://creativecommons.org/licenses/by/4.0/). 